\title{
Development-based Trust: Proposing and Validating a New Trust Measurement Model for Buyer-Seller Relationships
}

\author{
José Mauro da Costa Hernandez * \\ E-mail address: jmhernandez@usp.br \\ Escola de Artes, Ciências e Humanidades/Universidade de São Paulo - EACH/USP \\ São Paulo, SP, Brazil. \\ Claudia Cincotto dos Santos \\ E-mail address: ccincotto@gmail.com \\ Programa de Pós-Graduação em Administração/Universidade Nova de Julho - PPGA/UNINOVE \\ São Paulo, SP, Brazil.
}

\begin{abstract}
This study proposes and validates a trust measurement model for buyer-seller relationships. Baptized as development-based trust, the model encompasses three dimensions of trust: calculus-based, knowledge-based and identification-based. In addition to recognizing that trust is a multidimensional construct, the model also assumes that trust can evolve to take on a different character depending on the stage of the relationship. In order to test the proposed model and compare it to the characteristic-based trust measurement model, the measure most frequently used in the buyer-seller relationship literature, data were collected from 238 clients of an IT product wholesaler. The results show that the scales are valid and reliable and the proposed development-based trust measurement model is superior to the characteristic-based trust measurement model in terms of its ability to explain certain variables of interest in buyer-seller relationships (long-term relationship orientation, information sharing, behavioral loyalty and future intentions). Implications for practice, limitations and suggestions for future studies are discussed.
\end{abstract}

Key words: marketing; relationship marketing; trust; channel relationships; scale development.

Received 07 October 2008; received in revised form 21 August 2009.

Copyright (C) 2010 Brazilian Administration Review. All rights reserved, including rights for translation. Parts of this work may be quoted without prior knowledge on the condition that the source is identified.

\footnotetext{
* Corresponding author: José Mauro da Costa Hernandez

Rua Raul Pompéia, 905, apto. 154, São Paulo, SP, 05025-010, Brazil.
} 


\section{INTRODUCTION}

The study of trust among marketing channels has a long tradition in the marketing literature that spans over at least two decades. Although Dwyer, Schurr and Oh (1987) are usually referred to as the first authors to recognize the ultimate importance of including trust in the empirical models of marketing channel relationships, it was probably Morgan and Hunt (1994) that encouraged other studies in this area.

Several authors demonstrated that trust in the exchange partner leads to longer and more stable relationships, stimulates long-term orientation, reduces the incidence of conflict and uncertainty and boosts both satisfaction with the relationship, commitment and future purchase intentions (Anderson \& Narus, 1990; Anderson \& Weitz, 1989; Doney \& Cannon, 1997; Farrelly \& Quester, 2003; Ganesan, 1994; Morgan \& Hunt, 1994; Zhao \& Cavusgil, 2006).

Despite the importance of trust in channel marketing relationships, what we see after carefully revisiting studies in this field is that there is still widespread disagreement as to both the definition and measurement of this construct. This disagreement leads to a myriad of trust measures, casting suspicion on whether the trust measures used in these studies do actually measure trust.

It is not unusual to come across studies in which the conceptual definition of trust differs from its operational definition. Although trust has usually been defined as an expectation concerning the behavior of a prospective trustee (Anderson \& Narus 1990; Pavlou, 2002; Selnes, 1998), the most widely used measure is based on beliefs about the exchange partner characteristics (Doney \& Cannon, 1997; Morgan \& Hunt, 1994).

Considering the relevance of the trust concept to investigating buyer-seller relationships and the apparent confusion that a multitude of measures has caused, the study herein aims to propose and test a new trust measurement model. This model is based on the theoretical proposal of Lewicki and Bunker (1995) and its basic assumption states that trust is a multidimensional construct whose character may evolve according to the stage of the relationship. In addition to proposing a trust measurement model, named development-based trust, this study also tests it against the characteristicbased trust measurement model, the most widely used in studies of trust among marketing channels. The proposed model's advantages are to be grounded on a solid theoretical framework and be parsimonious enough so that it can be applied by both scholars interested in the study of marketing channel relationships and practitioners willing to improve their practices in the area of relationship marketing.

In order to meet the objectives proposed, this study is broken down into four sections. Initially, we look at how trust has been defined and measured in the literature of buyer-seller relationships, concluding with details of the proposed trust measurement model. The section after that describes the method used to test the proposed trust measurement model and the results immediately follow. Finally, the study's conclusions are discussed.

\section{LITERATURE REVIEW}

\section{The Problem of Defining Trust}

Trust has been recognized as essential to the stability of social relationships and vital for the maintenance of cooperation in society (Zucker, 1986). Trust reduces uncertainty about the future and the need to guard against others' opportunistic behavior, leading to harmony within organizations by eliminating friction and minimizing the need for bureaucratic structures. 
While most theoreticians agree on the importance of trust in social exchanges, there is hardly any consensus on how to define it (Gambetta, 1988). In this sense, Rousseau, Sitkin, Burt and Camerer (1998. p. 394) affirmed not long ago: "To date, we have had no universally accepted scholarly definition of trust". In general, trust definitions have been regarded as a "confusing pot-pourri" (Shapiro, 1987, p. 625) and a “conceptual confusion” (Lewis \& Weigert, 1985, p. 975).

One of the reasons usually alleged for this difficulty is the fact that although trust has frequently been an object of interest in various disciplines - psychology, sociology, political sciences, economics, anthropology, history and sociobiology (Gambetta, 1988), each one approaches the concept according to its own perspective. This diversity of approaches easily leads to the conclusion that trust has indeed dozens of definitions, each reflecting the paradigms of the researcher's discipline of interest (for longer reviews, see Rousseau et al., 1998).

Economists tend to view trust as an economic (Williamson, 1993) or institutional (North, 1990) phenomenon, sociologists see it as a property of relationships among people (Granovetter, 1985) or institutions (Zucker, 1986) and psychologists tend to focus on trust as a personality phenomenon (Rotter, 1967).

For instance, Rotter (1971), a personality theorist, defined interpersonal trust as a "generalized expectancy held by an individual that the word of another can be relied on" (p. 651). Among sociologists, Zucker (1986) defines trust as "a set of expectations shared by all those involved in an exchange, including both broad social rules (e.g., what a fair rate of interest would be) and the legitimately activated processes (e.g., who has the right to determine the rate of interest)" (p. 54). Boon and Holmes (1991), social psychologists, say that "trust is a state involving confident positive expectations about another's motives with respect to oneself in situations entailing risk" (p. 194). In the organizational literature, one of the most frequently mentioned definitions was coined by Mayer, Davis and Schoorman (1995), according to whom "trust is the willingness of one party to be vulnerable to the actions of another party based on the expectation that the other will perform a particular action important to the trustor, irrespective of the ability to monitor or control that other party" (p. 712). The latitude of different conceptions is so wide that it has led some authors to attempt the development of a taxonomy of trust concepts (Worchel, 1979).

Besides the tendency of scholars to adopt specific, biased perspectives, it is not uncommon for them to reject the views of other disciplines (Lewis \& Weigert, 1985). Furthermore, researchers tend to develop relatively narrow conceptualizations of trust that fit the type of research they carry out and, in order to enhance their results, they end up being guided by matters of internal consistency and external validity, usually at the expense of limiting the scope of the concept (McKnight \& Chervany, 2002).

\section{Trust in Buyer-seller Relationships: Concepts and Measures}

Several studies in the marketing relationship literature demonstrate that trust is indeed a core construct in buyer-seller relationships. For instance, it has been found that trust leads to longer and more stable relationships (Anderson \& Weitz, 1989; Pavlou, 2002), reduces the incidence of conflict (Morgan \& Hunt, 1994), boosts satisfaction with the relationship (Anderson \& Narus, 1990), minimizes uncertainty (Morgan \& Hunt, 1994), increases purchase intention (Doney \& Cannon, 1997), increases commitment (Farrelly \& Quester, 2003) and encourages long-term relationship orientation (Ganesan, 1994; Zhao \& Cavusgil, 2006).

Despite the broad agreement on the importance of the trust concept, it seems that there is no consensus when it comes to a definition. In relationship marketing literature, trust has commonly been defined as an expectation that the potential trustee will behave in such a way that will not jeopardize the trustor's interests (Anderson \& Narus, 1990; Pavlou, 2002; Selnes, 1998). However, also common are trust definitions built in terms of general expectations about the characteristics of the prospective trustee (Coulter \& Coulter, 2002; Doney \& Cannon, 1997; Morgan \& Hunt, 1994).

As occurs with definitions, the methods to measure trust in such studies also vary greatly. By and 
large, while the very earliest studies focused on global trust measures (Anderson \& Narus, 1990; Anderson \& Weitz, 1989), the studies published as of the second half of the 1990's have operationalized trust through beliefs about the characteristics of the prospective trustee such as credibility, honesty, competence, benevolence, integrity, predictability, responsiveness, sincerity or ability (Coulter \& Coulter, 2002; Doney \& Cannon, 1997; Farrelly \& Quester, 2003; Kingshott, 2006; MacMillan, Money, \& Downing, 2005; Pavlou, 2002; Zhao \& Cavusgil, 2006).

A judicious analysis of the trust measurement models usually adopted in channel relationship studies reveals at least two problems. Firstly, in many studies, the operational definition does not match the conceptual definition: while trust is defined in terms of expectations or beliefs about the prospective trustee's behavior, the measurement is grounded in beliefs about the trustee's characteristics. Secondly, in other studies, in order to overcome the previous contradiction somehow, the definition of trust is based on expectations about the characteristics of the prospective trustee, which is not trust in itself (Mayer et al., 1995).

Therefore, a standardized, broadly accepted measure of trust in channel relationships is necessary. Standard measures make it easier to consolidate studies in the same field, enable a more profound understanding of the phenomenon being studied and facilitate the exchange of knowledge among scholars and practitioners.

\section{Conceptualizing Trust in Buyer-seller Relationships}

In the business arena, there have been few attempts to develop trust scales. The few exceptions are the studies of McKnight, Choudhury and Kacmar (2002) and Bhattacherjee (2002) that developed a scale of trust for electronic commerce environments and the article of Delgado-Ballester, MunueraAlemán, and Yagüe-Guillén (2003) that developed a brand trust scale. To the limits of our knowledge, there is no previous study that developed a scale of trust for buyer-seller relationships.

Most probably, more researchers have not ventured into the development of trust scales because trust has traditionally been difficult to define (Rousseau et al., 1998). While many researchers preferred to define trust for their specific fields of study (Rempel, Holmes, \& Zana, 1985; Rotter, 1971; Zucker, 1986), others preferred to develop composite trust definitions (Kee \& Knox, 1970; Mayer et al., 1995). After examining a myriad of trust definitions and different points of view, we reached the conclusion that perhaps it is not possible to develop a sole definition for such a complex concept, one that would serve all disciplines or situations.

Despite that, in order to develop a new scale of trust for buyer-seller relationships, it is important to make difficult choices, and we chose to develop scales that operationalize the trust model proposed by Lewicki and Bunker (1995). This model possesses basically most of the qualities that a model for measurement trust in buyer-seller relationships would require.

First, the model of Lewicki and Bunker (1995) was designed to accommodate professional relationships such as those occurring in buyer-seller relationships. Some of the confusion regarding trust definitions arises due to the different referents that each researcher analyzes. For example, trust can exist at the level of people, groups, institutions, others in general or some combination of them (people and groups, people and institutions, people and others in general, etc.). Furthermore, the nature of the relationship may be personal, such as in romantic relationships (Boon \& Holmes, 1991) or professional, such as those occurring between employees of the same company (Shapiro, Sheppard, \& Cheraskin, 1992). By choosing the Lewicki and Bunker (1995) trust model, we wished to make sure that the framework could be easily adapted to the kind of relationship that occurs in buyer-seller relationships.

Second, it recognizes that trust is a multidimensional concept as has been already broadly accepted (Butler, 1991; Gabarro, 1978; Hosmer, 1995; Johnson-George \& Swap, 1982; Larzelre \& Huston, 1980; Mayer et al., 1995; Rempel et al., 1985; Rousseau et al., 1998; Shapiro et al., 1992). That is extremely important because assigning a single definition to trust might build in the risk of losing the 
wealth of the concept (Gabarro, 1978).

Third, and perhaps most importantly, it recognizes that the dynamics of trust are different at each stage of the relationship between the parties. As the relationship "moves from one stage to the other, the parties engage in different behaviors that are necessary both to develop and sustain the relationship” (Lewicki \& Bunker, 1995, p. 140).

One of the assumptions of the relationship marketing paradigm (Grönroos, 1994; Kotler, 1991; Webster, 1992) is that marketing management must focus on people, organizations and social processes that bind them together through continuous relationships. The focus changes from discrete transactions to a relational transaction, "which traces to previous agreements and ... is longer in duration, reflecting an ongoing process" (Dwyer et al., 1987, p. 13). Moreover, it has long been recognized that trust is essential for the relationship marketing success (Doyle \& Roth, 1992; Morgan \& Hunt, 1994).

To the best of our knowledge, the trust model advanced by Lewicki and Bunker (1995), along with the models of Boon and Holmes (1991) and Shapiro et al. (1992), is unique in recognizing that trust differs at each stage of the relationship. Finally, it is relatively parsimonious so that its operationalization can be applied by both scholars and pract0itioners alike.

In the Lewicki and Bunker model, trust may exist at three different levels: calculus-based, knowledge-based and identification-based. Specifically, they propose that initial trust has basically a calculative nature and may develop to the knowledge level as the parties assess the rate of previous successes and move on to the level of identification, where trust would be at its highest. Each of the dimensions that make up the model is examined in further details below.

\section{Calculus-based Trust}

Calculus-based trust refers to the acceptance of a certain level of vulnerability based on the calculated costs of maintaining or severing a relationship (Williamson, 1993). Calculus-based trust is not to be confused with deterrence-based trust, which is based on consistency of behavior sustained by the threat of punishment in case the consistency is not maintained (Shapiro et al., 1992). Nor should the concept of calculative trust be confused with the concept of value. Although value conceptualizations may vary depending on the study's context (Dodds, Monroe, \& Grewal, 1991), Zeithaml (1988) identified four common uses of the term: value is price, value is the trade-off between costs and benefits, value is the trade-off between quality and price and value is an overall assessment of subjective worth.

Calculative trust is an expectation based on the trade-off between risk and utility: given two courses of action involving the same amount of risk, one will choose the course that maximizes his utility. In buyer-seller relationships, when choosing partners that offer the same amount of risk, a buyer will probably decide to interact with the seller that maximizes his or her utility.

According to Coleman (1990), the decision to trust someone is like deciding to make a bet: the person knows how much may be lost, how much may be gained and the chance of winning. These are the only relevant elements. If the chance of winning, relative to the chance of losing, is greater than the amount that would be lost (if he loses), relative to the amount that would be won (if he wins), then by placing the bet he has an expected gain; and if he is rational, he should place it.

This simple expression is based on the postulation of maximization of utility under risk. The prospective trustor may decide not to trust, in which case his utility remains unchanged, or he may decide to trust, in which case the expected utility relative to his current status is the potential gain multiplied by the odds of winning minus the potential loss multiplied by the odds of losing. A rational actor will decide to trust if the first product is higher than the second; in other words, if the ratio between the odds of winning and losing is higher than the ratio between the amount at stake and the potential gain (Coleman, 1990). 
Some trust researchers (e.g., Kramer, 1994) have been surprised by discovering high levels of initial trust - by initial it is meant trust established between parties that first meet or interact. Calculus-based trust provides an excellent explanation for high levels of initial trust since trust choices are based on rationally derived utilities (Coleman, 1990; Williamson, 1993) and not on a history of interactions.

To clearly accommodate professional relationships like those occurring in marketing channel relationships, we define that calculative trust refers to a party's expectancy that buying from an exchange partner is more advantageous than not buying at all or buying from another party, and this expectancy is basically founded on the economic aspects of the transaction.

\section{Knowledge-based Trust}

Also sometimes referred as relational trust (Rousseau et al., 1998), knowledge-based trust develops with time as a result of the track record of interactions that enables both parties to develop generalized expectations about the other's behavior. In relationships, the parties nurture their knowledge of each other by collecting data from various different contexts and observing each other's reactions under different circumstances, thus developing the ability to predict each other's actions and reactions with considerable accuracy (Shapiro et al., 1992).

Regular communication and courtship are key processes for the development of knowledge-based trust (Shapiro et al., 1992). Through regular communication, the parties are in constant contact with each other, exchanging information about their needs, preferences and points of view about problems. Courtship, in turn, is a behavior specifically directed at the development of the relationship and is guided by interpersonal encounters, by observing each other's behavior in social environments, by experiencing different emotional states with the partner and learning how he behaves in different situations.

Different cultures assign to courtship different degrees of importance. For example, while Asian businessmen prefer to conduct long courtships with potential business partners, Western businessman think this process is tedious and costly, and give preference to short-term, limited, finite transactions (Shapiro et al., 1992).

Knowledge-based trust is grounded in the other's predictability and relies on information obtained during the relationship: the more one knows about the other party, the more he can accurately predict what the other party will do. Predictability enhances trust even if the other is predictably untrustworthy because it is possible to predict the ways that the other will violate the trust (Lewicki \& Bunker, 1995).

However, knowledge for the sake of knowledge is not enough to establish trust. Trust is built by assessing the success rate in previous transactions and predicting the success rate in future transactions. The higher the success rate of past encounters, the greater the trust. Therefore, we define knowledge-based trust as the party's belief that most of his previous transactions with an exchange partner were successful.

\section{Identification-based Trust}

Identification-based trust is grounded in deep knowledge of the partner's desires and intentions. Trust exists because the parties understand and appreciate each other's desires so that each one can effectively act on behalf of the other (Lewicki \& Bunker, 1995).

Jones and George (1998) attributed to identification-based trust the term unconditional trust. According to them, this kind of trust emerges when the partners move from a state of mere good will or willingness to exchange to a stage in which they identify with each other. There is total empathy with each other's desires and intentions and a mutual understanding that enables the parties to act on behalf of one another. In an environment of unconditional trust, people are more inclined to disclose information, since they feel more confident that others will not use that information to their own benefit, even when this knowledge is a source of power. 
Building up trust on identification is grounded on the knowledge and prediction of the other's preferences and needs and these needs and preferences are also shared. Identification enables one to feel, think and reply like his partner, resting on the structure of a collective identity, common values and shared activities and objects (Lewicki \& Bunker, 1995).

Here we define identification-based trust by the degree to which a party identifies with the exchange partner because he believes that they share similar values, preferences and needs.

\section{The Development of Trust}

In their research on romantic relationships, Boon and Holmes (1991) suggested that trust exists at three different stages: in the first, romantic love stage, trust and love tend to be undifferentiated; in the second, evaluative stage, real trust starts to appear; finally, in the third, accommodative stage, trust is solidified.

Shapiro et al. (1992) suggest that three types of trust operate in the development of a business relationship: deterrence-based trust, knowledge-based trust and identification-based trust. In Lewick and Bunker's (1995) model, deterrence-based trust of Shapiro et al.'s (1992) model is replaced by calculus-based trust. At the early stage of trust, calculus-based trust is partial and fragile; as the parties increase their mutual knowledge, learning as much as possible about each other and being able to predict each other's behavior, the mutual trust is not so fragile and is not necessarily broken by inconsistent behavior; identification-based trust is attained when one not only knows and predicts the other's needs, choices and preferences but also shares them. The parties know each other well enough to see themselves as a single identity. In Boon and Holmes (1991), trust changes its character as the relationship matures; in Shapiro et al.'s (1992) and Lewicki and Bunker's (1995) approaches, the three types of trust can coexist: it is not necessary for one type of trust to fade so that another type of trust can appear.

If a relationship goes through its full development into maturation, the movement is from calculusbased to knowledge-based to identification-based trust. However, as Lewicki and Bunker point out, not all relationships develop fully and trust may not develop past the first or second stage. For one reason or another, trust declines and the relationship can bounce back, for example, from knowledgebased to calculus-based trust. At any time, one party may have the three different types of trust in different degrees towards his or her partner. Graphically, the model can be represented as in Figure 1.

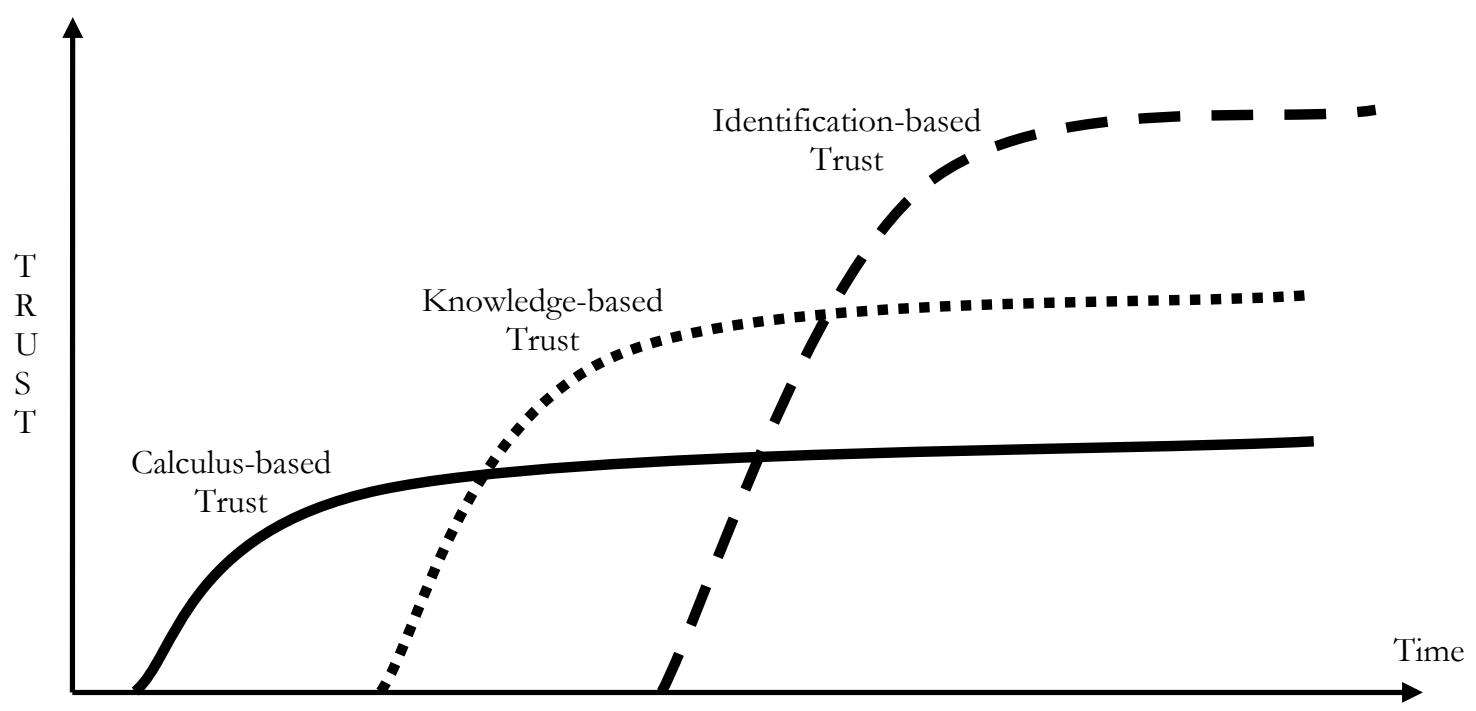

Figure 1: Graphic Representation of the Development-based Model 


\section{The Development-based Trust Model for Measurement Trust in Buyer-Seller Relationships}

Based on the Lewicki and Bunker's model, we propose a model for measuring trust in buyer-seller relationships that includes three types of trust: calculus-based, knowledge-based, and identificationbased trust (Figure 2). The model is christened development-based model because it assumes that trust develops throughout the stages of the relationship. Although Lewicki and Bunker's model is frequently mentioned in the trust literature, to the best of our knowledge, the model has never been operationalized before.

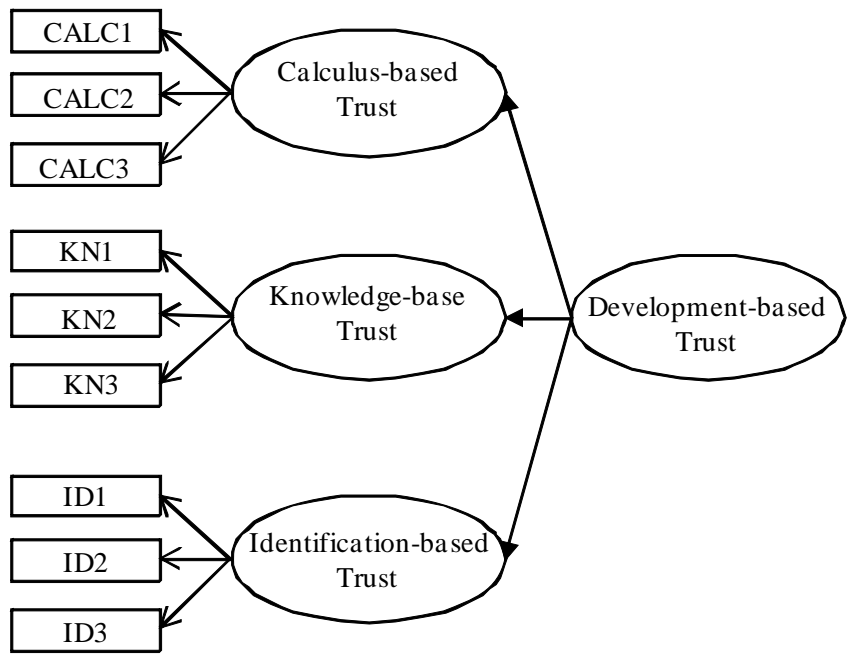

Figure 2: Development-based Trust for Buyer-seller Relationships

Two characteristics of this model deserve to be emphasized. First, following Lewicki and Bunker (1995), the model recognizes that the three types of trust may exist at the same time, and all of them are different dimensions of trust.

Second, the model is built following a more conservative paradigm for the development of scales (Anderson \& Gerbing, 1982; Churchill, 1979) and all the indicators are modeled as reflective constructs rather than formative constructs (Jarvis, Mackenzie, \& Podsakoff, 2003). This is true also for the second-order measurement model of Figure 2 in which the three types of trust are caused by the development-based trust. Basically, this more conservative paradigm "assumes the classical test theory in which the variation in the scores on measures of a construct is a function of the true score, plus error" (Jarvis et al., 2003, p. 200). The consequence is that the underlying latent construct causes the observed variation in the measures (Nunnally, 1978) and not the opposite.

To test the nomological validity of the model, we hypothesize that trust has a positive impact on variables of interest for relationship marketing (Figure 3). Based on the results of previous studies, four constructs have been chosen as dependent variables to test the model: two sub-constructs of Lages, Lages and Lages' (2005) relationship quality scale (long-term orientation and information sharing) (Wong \& Sohal, 2002), behavioral loyalty (Dick \& Basu, 1994; Sirdeshmukh, Singh, \& Sabol, 2002) and future intentions (Doney \& Cannon, 1997). 


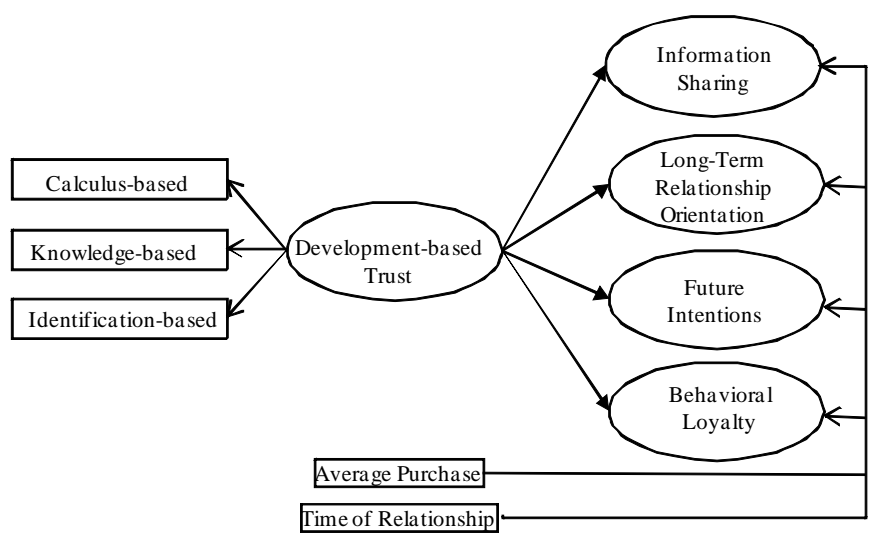

Figure 3: The Nomological Net of the Development-based Trust Model for Buyer-seller Relationships

Although they are not of primary interest, we include in the nomological validity test two variables that control for extraneous effects - time of relationship measured by the time that the relationship has endured and intensity of relationship measured by the average value of purchases made during the relationship.

It has been frequently assumed that trust develops gradually over time as a result of past interactions (Rempel et al., 1985). Furthermore, Lewicki and Bunker (1995) posit that knowledge-based trust develops over time as parties cultivate their knowledge of each other by gathering data, seeing each other in different contexts and living different experiences together, and that a long relationship is necessary before identification-based trust is born. Therefore, by including the time of relationship in the model, we expect to rule out the effect of time on trust development.

The reason for including as a control variable the intensity of relationship is that one could argue that a relationship is not explained only by the time it has endured but also by its intensity. For example, one could be an old client but does not buy frequently or buys low volumes while another client could be a new one but buys more frequently and buys higher volumes. The average value of purchases encompasses both a measure of the number of purchases made during the relationship as well as the value of these purchases. Although these two variables do not have substantive interest in the model, their major purpose is to remove statistical noise and provide for a stronger test of our model of trust measurement.

We chose a competing model (Figure 4) that is grounded solely on the characteristics of the prospective trustee, which is the model most commonly employed in studies of channel relationships. The competing model has the same configuration of the proposed model and, hypothetically, the better the trust measurement model, the better its ability to explain the dependent variables.

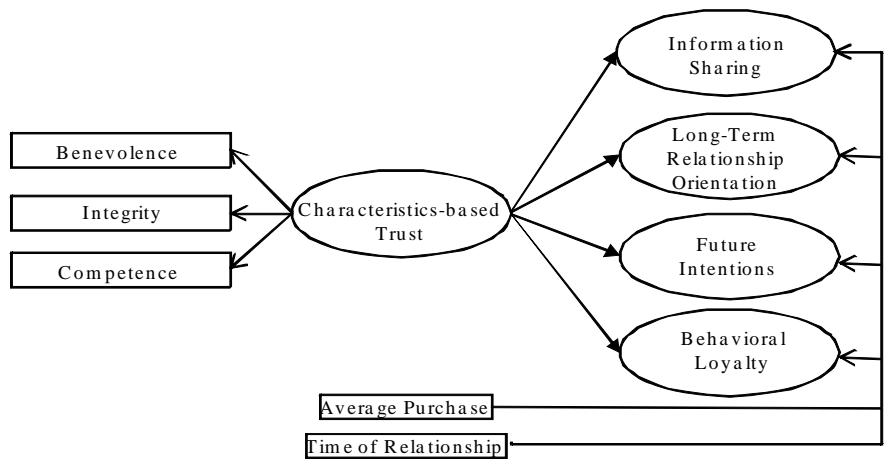

Figure 4: Characteristics-based Trust Measurement 


\section{METHOD}

Data to test the two competing models were collected from a conveniently chosen sample of clients (dealers) of a Brazilian distributor of IT products (wholesaler). This wholesaler specialized in distributing connectivity, security and Internet products of 17 different brands such as 3COM, Dlink, Suse Linux and Citrix.

The database of this wholesaler holds information on more than 15,000 dealers, of which about 3,000 buy at least once every 45 days. Clients of this distributor range from IT product stores that sell directly to individual customers to small and medium-sized companies that provide IT consultancy services and even heavyweights such as IBM that sells its own products but needs certain components for the solutions they design.

Usually, at the start-up of a project for a client, dealers inform the wholesaler of items they intend to purchase and request a price quote from several wholesalers. The dealer expects that, in addition to offering the best sales terms so as to help it win the tender, the wholesaler will not disclose any information about his client. The wholesaler, by the same token, expects the dealer not to mention its price quote to haggle for better terms with other wholesalers. This is therefore a very favorable environment to study trust between marketing channels.

\section{Procedures}

There are several favorable reasons to collect data though the Internet such as flexibility, speed and timeliness, convenience, low administration cost, ease of follow-up, among others (Evans \& Mathur, 2005) although there are also several other unfavorable reasons such as skewed attributes of Internet population (age, education, etc.), privacy issues, impersonality, low response rate, among others (Evans \& Mathur, 2005).

Taking into consideration the broad geographical distribution and the natural involvement of interviewees with computers and Internet, an electronic questionnaire appeared to be the most suitable strategy for collecting data. The questionnaire remained online for 30 days during October and November of 2006.

Electronic messages were sent out to 4,416 buyers, managers or owners of 2,155 dealers who had made at least one purchase at the wholesaler over the previous 12 months. This 12-month period was established for the purpose of ensuring that the sample would include only those companies engaging in an active relationship with the wholesaler. In order to boost the response rate, the possibility to enter a lottery to win an Ipod was offered to dealers that completed the questionnaire and an electronic follow-up was sent two weeks after the initial batch.

\section{Scale Development}

Churchill (1979) suggested several processes for generating the initial sample of items including literature search, experience surveys, critical incidents and focus groups. In this study, due to the richness of knowledge about trust, we strongly relied on literature search. Further, we qualitatively interviewed 2 clients of an IT wholesaler before the scales development and pre-tested the questionnaire with 3 other potential respondents.

The number of items of each trust sub-construct scale was defined based on recently developed trust scales: For example, Bhattacherjee's (2002) scale of trust in electronic commerce has 6 items for 3 sub-constructs and McKnight et al.'s (2002) scale of trust in electronic commerce has 54 items for 16 sub-constructs (an average of 3.3 items per sub-construct). Considering that it is common to drop some items during the purification process of a scale but that an excessive number of items can result 
in redundancy and lack of parsimony, we decided to start the process with 4 items for each of the 3 sub-constructs.

The first step was to define as exactly as possible the domain of content for each construct of the development-based trust measurement model. The calculus-based trust's definition states that it refers to expectations about the economic benefits of a purchase such as lower prices, better commercial terms and more convenience. One of the clients interviewed suggested the inclusion of expectations about the exclusivity of products and brands offered. According to him, in the IT market, some wholesalers have exclusive rights of distribution of some brands and this exclusivity can represent economic advantages both for distributors and their clients.

Specifically, the statements asked respondents to consider both expectations about the risks involved in the purchase and the economic benefits that could accrue from the purchase (e.g. "Despite the risks, I prefer to buy from the wholesaler because it always has the lowest prices"). During the questionnaire pre-test, the clients interviewed affirmed that the statements were odd because they did not perceive the risks involved in purchasing from well known distributors and this part of the statements was dropped in the final questionnaire. Further, we considered that writing the statements around preferences was not in line with the conceptual definition and rephrased them to take into account expectations rather than preferences (e.g., "I always expect the prices of the wholesaler to be lower than the prices of other distributors").

The content domain of the knowledge-based trust sub-construct includes only beliefs of satisfaction with the history of previous transactions and the 4 statements were written around these beliefs (e.g., "Most of the times I purchased from the wholesaler I had no problems"). The domain of the identification-based sub-construct includes only affective feelings towards the partner (e.g., "I have great esteem for the wholesaler”).

The items were written as positive statements because negative statements could be confused with distrust (Wrightsman, 1991), a concept different from trust (Lewicki, McAllister, \& Bies, 1998). All the statements were evaluated by 5 -point Likert type scales ( $1=$ totally disagree; 5 =totally agree).

In order to measure the construct relating to characteristics-based trust, in accordance with the construct definition and grounded on a number of studies (for instance, Ganesan, 1994), six items were developed that sought to capture the dealers' belief in the benevolence, integrity and competence of the wholesaler (e.g., “The wholesaler tries to help his clients rather than just look out for himself”).

The relationship quality was operationalized by two sub-constructs - information sharing and longterm relationship orientation. The items were adapted from the relationship quality scale proposed by Lages et al., (2005) and measured by a 5-point Likert type scale (1=totally disagree; 5=totally agree). Future intentions were operationalized by means of 4 items commonly found in the marketing literature (e.g., "Do you intend to continue buying from the wholesaler in the future?”) and were also measured by a 5 point scale ( $1=$ certainly no; $5=$ certainly yes). Finally, three items operationalized the behavioral loyalty scale. The first item ("From how many different distributors did you buy last year?" was anchored by 6 categories (more than $10=1$; between 1 and 2=6), the second item ("Taking into consideration all of your suppliers, what is the relative importance of the wholesaler?”) was anchored by 7 categories (this wholesaler is not among my main suppliers $=1$; this wholesaler is my main supplier=7), and the third item ("What percentage of your total purchases were made from the wholesaler?") was anchored by 9 items (between $1 \%$ and $5 \%=1$; more than $75 \%=9$ ).

The items described above are featured in Appendix I along with some descriptive statistics. Finally, data for control variables were retrieved from the wholesaler's client database. 


\section{RESULTS}

A total of 238 questionnaires were answered, for a response rate of 5.4\%. Although this figure can be considered fairly low, it is in line with previous studies that concluded that response rates of electronic surveys are generally lower than mail surveys (Shih \& Fan, 2008). Despite this fact, several studies were not able to find significant differences between the quality of data collected through the Internet and other methods (Coderre, Mathieu, \& St-Laurent, 2004; Deutskens, Ruyter, \& Wetzels, 2006; McDonald \& Adam, 2003; Roster, Rogers, Albau, \& Klein, 2004) suggesting that data obtained through electronic surveys are no worse than data collected through other methods.

It is commonly argued that a low response rate can potentially lead to non-response bias, but recent studies have demonstrated that there is no necessary connection between nonresponse rates and nonresponse bias (Groves, 2006). While there are known methods for identifying the non-response bias (see, for example, Singer, 2006), correcting this bias is only possible when there are external data to estimate the bias or the non-respondents are contacted after the data collection. In the present study, neither of these remedies was available but analyses of the sample data suggest a large variety of respondent's demographics which decreases the potential of nonresponse bias.

For example, among the respondents, 76\% were male, 85\% were between 26 and 50 years old and $56 \%$ reported that they had obtained at least a graduate degree; $50 \%$ were partners or top managers in their companies, $23 \%$ were technical or sales managers, and $27 \%$ were buyer officers.

According to the respondents, 32\% had made their first purchase from the wholesaler more than five years ago and only $15 \%$ had made their first purchase less than one year ago. For $41 \%$ of the respondents, the wholesaler in question was the first or second most important supplier and for $19 \%$ of the respondents the wholesaler in question did not feature among the top five IT product suppliers.

Data obtained from the wholesaler's database showed that, on average, respondents had made their first purchase from the distributor 5.6 years before the data collection (s.d.=4.1 years). On average, wholesaler's clients of the sample had made 86 purchases (s.d.=176) totaling US\$234,000 $(\mathrm{s.d} .=658,000)$ and the average value of purchases was US\$1,451 (s.d.=US\$2,477).

Analyses of variance followed by Scheffé post-hoc tests were performed to verify whether there were significant differences in answers from different groups of respondents. Twelve variables from the development-based model, 6 variables from the characteristics-based model, and 12 dependent variables were analyzed.

The results revealed no significant differences $(\mathrm{p}<0.01)$ for the status of the respondents in the company (partner, director, manager or buyer), the company's number of employees, company's gross sales, sex, age and education. Therefore, although the sample included a large variety of respondents, the ANOVAs suggest that the sample variety had no influence on the results.

\section{Validity and Reliability of the Scales}

The scale validity and reliability analyses were staggered in two steps. The first, an exploratory step, featured a principal components factor analysis, and the results were submitted to an orthogonal rotation. Although some correlation among the different measures could be expected, an orthogonal rotation provides a stricter test of the unidimensionality of the constructs.

The characteristic-based trust items and the measurement items of the calculus-based, knowledgebased and identification-based were analyzed separately since they are alternative measurement models. Likewise, the dependent variables items used to test the models (long-term relationship orientation, information sharing, behavioral loyalty and future intentions) were also analyzed separately. 
The purpose of the exploratory factorial analysis was to eliminate items that did not have factorial loadings higher than 0.5 in their respective factors (Hair, Anderson, Tatham, \& Black, 1998) or had cross loadings higher than 0.4 (Churchill, 1979). The following criteria were adopted for the exploratory factorial analysis: extracted communality of the items higher than 0.5 , the sphericity test of Bartlett significant at a 5\% level and the Kaiser-Meyer-Olkin test higher than 0.7 (Hair et al., 1998). A minimum lower threshold of 0.7 for the Cronbach's Alpha coefficient was established (Nunnally, 1978).

In the second step, a confirmatory factorial analysis was carried out using structural equation modeling with Lisrel 8.51 (Jöreskog \& Sörbon, 1996). As suggested by Anderson and Gerbing (1998), this analysis was done in two steps. In the first step, we analyzed only the measurement model of both sets of dependent and independent variables separately and in the second step we analyzed the structural model of the two competing models of trust measurement.

The confirmatory factorial analysis checks for convergent validity (Schwab, 1980) and discriminant validity (Bagozzi, Yi, \& Phillips, 1991). The criteria used to check for convergent validity included lambda matrix standardized coefficients higher than 0.60 and significant at a $5 \%$ level, that is, at least twice the respective standard deviation (Anderson \& Gerbing, 1998). Also, the modification indices suggested by the program were checked for cross loadings. Convergent reliability was assessed also by means of composite reliability and average variance extracted. Following Fornell and Lacker (1981), constructs are convergent when the reliability exceeds 0.7 and average variance extracted exceeds 0.5 .

The discriminant validity of latent constructs was checked using inter-correlation coefficients between them (PHI and PSI matrices): values below 0.60 indicate independent constructs (Anderson \& Gerbing, 1998). Inter-correlations among the constructs obtained from the average of the items were also analyzed for excessive values (higher than 0.6 ).

In order to assess the fit of the models, the following criteria were used: GFI and AGFI higher than 0.90 (Hu \& Bentler, 1995), NFI and CFI also higher than 0.90 (Bentler, 1990), RMSEA lower than 0.08 for a considerable fit and 0.05 for a good fit (MacCallum, Browne, \& Sugawara, 1996) and RMR lower than 0.05 (Hu \& Bentler, 1995).

\section{Exploratory Factorial Analysis}

In the first exploratory factorial analysis, the 12 items of the three trust sub-constructs of the proposed trust model were analyzed. As expected, three factors produced eigenvalues higher than 1 and were responsible for $67.3 \%$ of explained variance. One of the items (CAL4) was dropped from subsequent analyses because its extracted communality was inferior to 30\% and two items (KN4 and ID4) were dropped because they loaded highly ( $>0.4)$ in constructs other than their own.

A new analysis with the remaining 9 items revealed that 3 factors were responsible for $75 \%$ of the explained variance, the extracted communality was higher than 0.6 for all the items, the factorial loadings were higher than 0.6, there were no cross-loadings superior to 0.4, the Bartlett sphericity test was significant $\left(\mathrm{X}^{2}=1025,36\right.$ d.f., $\left.\mathrm{p}<0.001\right)$ and the Kaiser-Meyer-Olkin test was equal to 0.85 . The Cronbach's Alpha coefficients for the 3 constructs were higher than 0.7.

In the subsequent exploratory factorial analysis, 6 characteristic-based trust items were analyzed. As expected, only one factor produced an eigenvalue higher than 1 for a total explained variance of $59.9 \%$. The extracted communality of the 6 items was higher than $50 \%$, the Bartlett sphericity test was significant $\left(\mathrm{X}^{2}=612,15\right.$ d.f., $\left.\mathrm{p}<0.001\right)$ and the $\mathrm{KMO}$ test was equal to 0.86 . The factorial loadings of all items were higher than 0.7 and the value of the Cronbach’s Alpha coefficient equaled 0.86.

In the third exploratory factorial analysis, the 12 items relating to the dependent variables were analyzed. As expected, four of the obtained factors produced eigenvalues higher than 1 , responsible for $75 \%$ of total variance. The extracted communality was higher than $60 \%$ for all items. The Bartlett 
sphericity test was significant $\left(\mathrm{X}^{2}=1424,66\right.$ d.f., $\left.\mathrm{p}<0.001\right)$. The factorial loadings of all items in their respective constructs was higher than 0.7 and no cross loadings were higher than 0.4 . The Cronbach's Alpha coefficients were higher than 0.7 for all four constructs.

\section{Confirmatory Factorial Analysis}

Appendix 2 features the correlations among the 29 variables used in the confirmatory factorial analyses that tested the two competing models of trust measurement. Most of the inter-correlations were significant $(\mathrm{p}<0.05)$ and the average correlation was 0.31. A major part of the higher correlations, however, was found among items of the same construct. From 406 inter-correlations, only $45(11 \%)$ were higher than 0.5 and 78 (19\%) were between 0.4 and 0.5 . These results suggest that there was enough variability to support the following confirmatory factorial analyses and their conclusions.

Figure 5 shows standardized coefficients obtained from the second order confirmatory factorial analysis of the 9 items corresponding to the three latent sub-constructs of development-based trust. The fact that all coefficients remained within the established limits leads to the conclusion that the model has a good fit. Constructs also met the convergent validity test since all lambda matrix coefficients ranged from 0.56 to 0.90 and were significant at a $0.1 \%$ level. The second-order construct, development-based trust, was responsible for $51 \%$ of the variance in calculus-based trust, $59 \%$ in knowledge-based trust, and 85\% in identification-based trust.

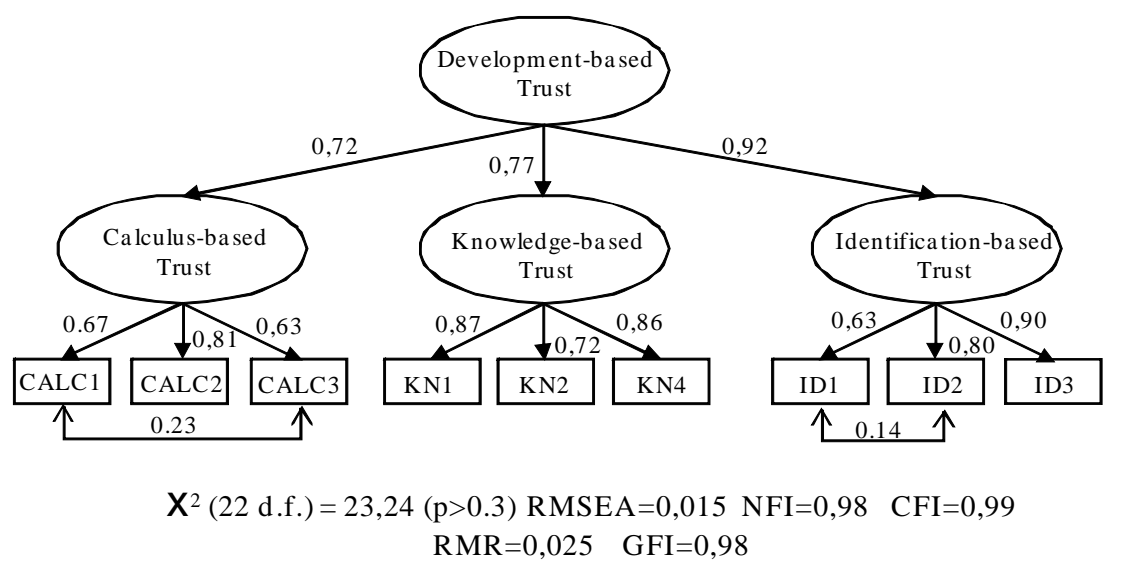

Figure 5: Second-order Measurement Model of Development-based Trust Model

As can be seen in Table 1, the 3 sub-constructs met both convergent and discriminant validity criteria. Composite reliabilities ranged between 0.75 and 0.86 , average variance extracted ranged between 0.50 and 0.62 and correlations ranged between 0.35 and 0.45 .

Table 1:

Cronbach's Alpha, Composite Reliability and Average Variance Extracted of Developmentbased Trust Model

\begin{tabular}{|c|c|c|c|c|c|c|c|}
\hline \multirow[b]{2}{*}{ Construct } & \multirow[b]{2}{*}{$\begin{array}{l}\text { Number } \\
\text { of Items }\end{array}$} & \multirow[b]{2}{*}{$\begin{array}{c}\text { Cronbach } \\
\text { Alpha }\end{array}$} & \multirow[b]{2}{*}{$\begin{array}{l}\text { Composite } \\
\text { Reliability }\end{array}$} & \multirow[b]{2}{*}{ AVE } & \multicolumn{3}{|c|}{ Factor Correlations } \\
\hline & & & & & $\begin{array}{l}\text { Calculative- } \\
\text { based Trust }\end{array}$ & $\begin{array}{l}\text { Knowledge- } \\
\text { based Trust }\end{array}$ & $\begin{array}{c}\text { Identification- } \\
\text { based Trust }\end{array}$ \\
\hline $\begin{array}{c}\text { Calculative-based } \\
\text { trust }\end{array}$ & 3 & 0.76 & 0.75 & 0.50 & 1 & & \\
\hline $\begin{array}{c}\text { Knowledge-based } \\
\text { trust }\end{array}$ & 3 & 0.86 & 0.86 & 0.67 & 0.35 & 1 & \\
\hline $\begin{array}{l}\text { Identification-based } \\
\text { trust }\end{array}$ & 3 & 0.85 & 0.82 & 0.62 & 0.37 & 0.45 & 1 \\
\hline
\end{tabular}


Figure 6 shows the standardized coefficients obtained from the confirmatory factorial analysis of the 12 items corresponding to the four constructs relating to the variables of interest used to test both trust measurement models. All coefficients remained within the previously established limits leading to the conclusion that the model had a good fit. Likewise, constructs are convergent since the lambda matrix coefficients varied between 0.61 and 0.93 (within the established limits) and all proved significant at a $0.1 \%$ level. The inter-correlations between latent constructs varied between 0.49 and 0.62 , demonstrating that all constructs met the discriminant validity test.

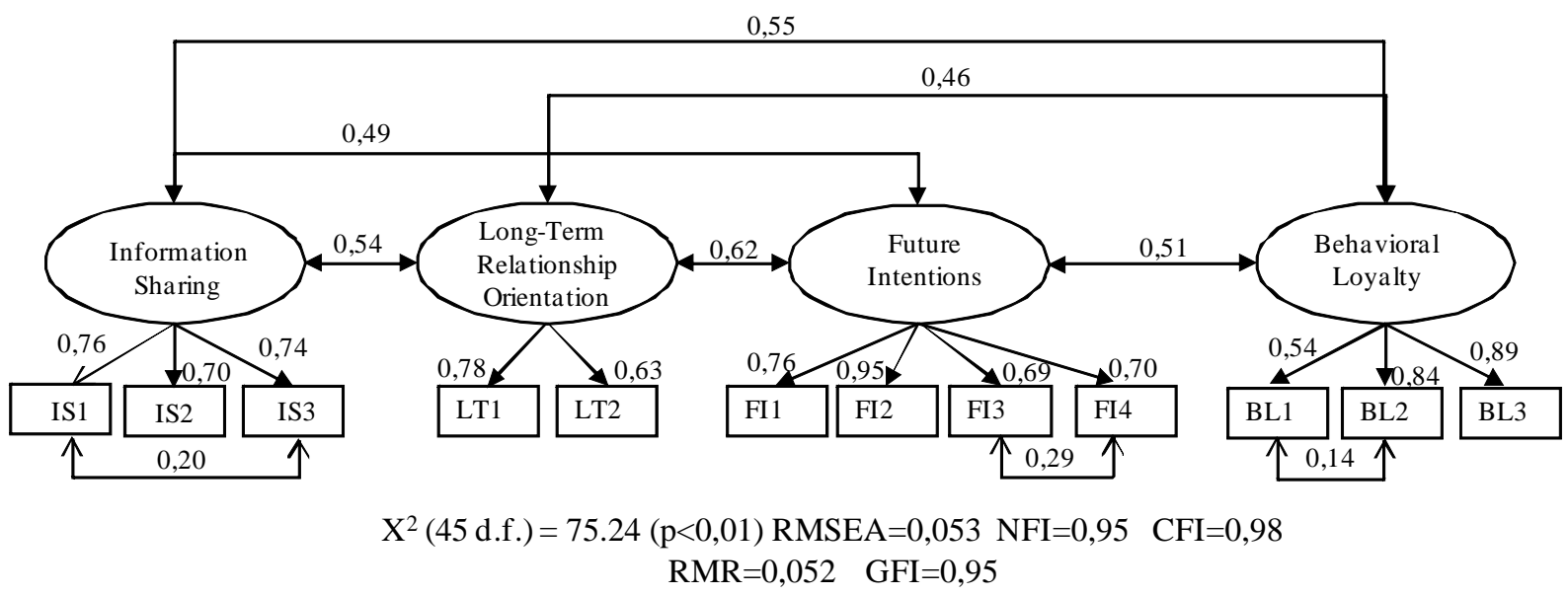

Figure 6: Measurement Model - Dependent Variables

As it is seen in Table 2, Cronbach's Alpha, composite reliability, and average variance extracted are within the limits for 3 of the constructs but long-term relationship. This is due to the fact that this measure was composed of only 2 items. However, both Cronbach's Alpha and composite reliability are very close to the limit of 0.70 and were maintained in the test of competing models of trust measurement.

Table 2:

Cronbach's Alpha, Composite Reliability and Average Variance Extracted of Dependent Variables

\begin{tabular}{|c|c|c|c|c|c|c|c|c|}
\hline \multirow[b]{2}{*}{ Construct } & \multirow[b]{2}{*}{$\begin{array}{l}\text { Number } \\
\text { of } \\
\text { Items }\end{array}$} & \multirow[b]{2}{*}{$\begin{array}{l}\text { Cronbach } \\
\text { Alpha }\end{array}$} & \multirow[b]{2}{*}{$\begin{array}{l}\text { Composite } \\
\text { Reliability }\end{array}$} & \multirow[b]{2}{*}{ AVE } & \multicolumn{4}{|c|}{ Factor Correlations } \\
\hline & & & & & $\begin{array}{l}\text { Information- } \\
\text { Sharing }\end{array}$ & $\begin{array}{c}\text { Long-term } \\
\text { Relationship } \\
\text { Orientation }\end{array}$ & $\begin{array}{c}\text { Future } \\
\text { Intentions }\end{array}$ & $\begin{array}{c}\text { Behavioral } \\
\text { Loyalty }\end{array}$ \\
\hline Information-Sharing & 3 & 0.82 & 0.78 & 0.54 & 1 & & & \\
\hline $\begin{array}{l}\text { Long-term Relationship } \\
\text { Orientation }\end{array}$ & 2 & 0.66 & 0.67 & 0.50 & 0.41 & 1 & & \\
\hline Future Intentions & 4 & 0.88 & 0.86 & 0.61 & 0.40 & 0.43 & 1 & \\
\hline Behavioral Loyalty & 3 & 0.77 & 0.81 & 0.60 & 0.40 & 0.32 & .35 & 1 \\
\hline
\end{tabular}

\section{Testing the Competitive Models}

Taking into consideration the relationship between the various latent constructs, structural equation modeling is very appropriate for testing the two competing models. Table 3 shows both models afford a good fit. The question could be raised that the proposed model is less parsimonious than the characteristic-based because the first comprises 9 items and three sub-constructs while the second comprises 6 items and only one sub-construct. However, fit indices that take into account the parsimony of the model (PNFI and PGFI) are very close (Table 3). 
Table 3:

Adjustment Measures of Competing Trust Measurement Models

\begin{tabular}{lcc}
\hline $\begin{array}{c}\text { Adjustment } \\
\text { Measure }\end{array}$ & $\begin{array}{c}\text { Characteristic- } \\
\text { based Trust Model }\end{array}$ & $\begin{array}{c}\text { Development- } \\
\text { based Trust Model }\end{array}$ \\
\hline Chi-square & $\begin{array}{c}278.0(156 \text { d.f. }) \\
(\mathrm{p}<0.001)\end{array}$ & $\begin{array}{c}196,6(105 \text { d.f. }) \\
(\mathrm{p}<0.001)\end{array}$ \\
RMSEA & 0.062 & 0.062 \\
NFI & 0.880 & 0.900 \\
CFI & 0.940 & 0.950 \\
RMR & 0.076 & 0.075 \\
GFI & 0.890 & 0.910 \\
PNFI & 0.730 & 0.690 \\
PGFI & 0.660 & 0.620 \\
\hline
\end{tabular}

Although the fit of competing models are similar, as expected, the proposed development-based trust model offers higher explanatory ability of the dependent variables than the characteristics-based trust measurement model (Table 4).

Table 4:

Structural Equation Squared Correlation Coefficients (r2) of the Characteristics-based and Development-based Trust Measurement Model

\begin{tabular}{lcc}
\hline \multicolumn{1}{c}{ Variables } & $\begin{array}{c}\text { Characteristics } \\
\text { Trust Model r }{ }^{2}\end{array}$ & $\begin{array}{c}\text { Development- } \\
\text { based Trust } \\
\text { Model r }^{2}\end{array}$ \\
\hline $\begin{array}{l}\text { Dependent Variables } \\
\text { Information Sharing }\end{array}$ & 0.37 & 0.52 \\
Long-term Relationship Orientation & 0.54 & 0.59 \\
Future intentions & 0.52 & 0.61 \\
Behavioral Loyalty & 0.32 & 0.42 \\
\hline
\end{tabular}

Table 5 shows that standardized coefficients of the development-based trust model are slightly higher than the standardized coefficients of the characteristics-based trust model, which in is line with the higher ability of explanation of dependent variables demonstrated in figures of Table 4. Therefore, considered collectively, the results suggest that the proposed development-based trust measurement model cannot be rejected and that it outperforms the characteristics-based trust in its ability to explain the dependent variables. 
Table 5:

Standardized Coefficients of Competing Models of Trust Measurement

\begin{tabular}{lcc}
\hline \multicolumn{1}{c}{ Pathway } & $\begin{array}{c}\text { Standardized } \\
\text { Coefficient }\end{array}$ & Sig. \\
\hline Characteristic-based Trust Measurement Model & & \\
Characteristic Trust $\rightarrow$ Information Sharing & 0.54 & $\mathrm{p}<0.01$ \\
Characteristic Trust $\rightarrow$ Long-Term Relationship Orientation & 0.73 & $\mathrm{p}<0.01$ \\
Characteristic Trust $\rightarrow$ Future Intentions & 0.72 & $\mathrm{p}<0.01$ \\
Characteristic Trust $\rightarrow$ Behavioral Loyalty & 0.45 & $\mathrm{p}<0.01$ \\
Development-based Trust Measurement Model & & \\
Development-based Trust $\rightarrow$ Information Sharing & 0.69 & $\mathrm{p}<0.01$ \\
Development-based Trust $\rightarrow$ Long-Term Relationship Orientation & 0.77 & $\mathrm{p}<0.01$ \\
Development-based Trust $\rightarrow$ Future Intentions & 0.78 & $\mathrm{p}<0.01$ \\
Development-based Trust $\rightarrow$ Behavioral Loyalty & 0.61 & $\mathrm{p}<0.01$ \\
\hline
\end{tabular}

Based on these results, it is possible to conclude that the higher the development-based trust, the higher the level of information sharing, the higher the dealers' orientation towards long-term relationship with the wholesaler, the higher the future intentions towards the wholesaler and the higher the dealers' behavioral loyalty towards the wholesaler.

It is important to emphasize that time of relationship was not associated with any of the dependent variables while relationship intensity measured by the average value of purchases is positively associated only to information sharing and to behavioral loyalty but not to long-term relationship orientation neither to future intentions.

To demonstrate further the nomological validity of the proposed trust measurement model, we conducted additional analyses. We split the sample into three groups according to the total development-based trust obtained by averaging the indicators of the three types of trust (calculusbased, knowledge-based and identification-based). This procedure is reasonable because the secondorder confirmatory factorial analysis demonstrated that three latent sub-constructs of trust are in fact a measure of the latent second-order construct, development-based trust.

The sample was split by the quartiles, i.e., the first group (low trustors) and third group (high trustors) comprised 25\% of the sample and the second group (average trustors) comprised $50 \%$ of the sample. Hypothetically, the higher the dealer's trust toward the wholesaler, the stronger the dealerwholesaler relationship. This split makes sense in comparative terms (the objective here) and the measures are not intended to be taken as absolute measures of trust.

Five measures were compared through Anova tests: months since first purchase, number of purchases made from the wholesaler, average value of purchases (these three variables were retrieved from the wholesaler's database), stated trust towards the wholesaler ("I place a great deal of trust in this wholesaler" measured by a 5-point Likert type scale), and stated intention to buy less/more in the future measured by a 5 -point scale ( $1=$ much less; $5=$ =much more).

As can be concluded by examining Table 6 the higher the development-based trust, the longer since the dealer has made his first purchase from the wholesaler, the higher the number of purchases made from the wholesaler, the higher the average value of purchases, the higher the stated trust towards the wholesaler and the higher the intention to buy more in the future. These results strengthen the conclusions about the nomological validity of the development-based trust model. 
Table 6:

\section{Development-based Trust Levels and Relationship Variables}

\begin{tabular}{lrrrrrr} 
& \multicolumn{7}{c}{ Total Development-based Trust } \\
\cline { 2 - 7 } & Low & Average & High & Total & Sig. \\
\hline Relationship Variables & 3.1 & 4.0 & 4.7 & 3.9 & $\mathrm{p}<0.01$ \\
\hline Months since the first purchase & 54 & 69 & 76 & 67 & $\mathrm{p}<0.05$. \\
Number of purchases & 34 & 82 & 146 & 86 & $\mathrm{p}<0.01$ \\
Average value of purchases (US\$ 000) & 831 & 1,476 & 2,022 & 1,451 & $\mathrm{p}<0.05$ \\
I have a high trust towards this wholesaler & 3.3 & 4.3 & 4.7 & 4.2 & $\mathrm{p}<0.01$ \\
I intend to buy less/more in the future & 3.7 & 4.0 & 4.4 & 4.1 & $\mathrm{p}<0.01$ \\
\hline $\mathrm{N}$ & 60 & 118 & 60 & 238 & \\
\hline
\end{tabular}

\section{CONCLUSION}

Despite the vast amount of studies about trust in the marketing literature, there have been few attempts to develop theoretically valid and reliable scales to measure the construct. This is even more striking considering that trust has long been accepted as a core construct for the relationship marketing literature (Morgan \& Hunt, 1994).

Over ten years ago Geyskens, Steenkamp and Kumar (1998) did an excellent job in summarizing the impact of trust in marketing channel relationships, but at the time they did not question whether the concepts adopted or the scales used so far were theoretically acceptable. However they did point out that the variety of scales reviewed had indeed made their attempt to consolidate the results more challenging.

Recent studies have aimed to develop trust measures for other areas of marketing such as electronic commerce (Bhattacherjee, 2002; McKnight et al., 2002) and branding (Delgado-Ballester et al., 2003) but nobody has yet taken the trouble to develop a trust scale for buyer-seller relationships. The attempt of this study is to fill this void by proposing and validating a trust measurement model for buyer-seller relationships that, besides recognizing that trust is a multidimensional construct, is grounded in a theoretical framework that suggests that trust exists at different levels depending on the relationship stage.

The results show that the scales proposed to measure the three types of trust - calculus-based, knowledge-based and identification-based - are valid and reliable. The results also demonstrate that the three sub-constructs are sub-constructs of a second-order, development-based trust. Finally, the results show that, compared with the characteristic-based, the measurement model most widely used in the buyer-seller relationship literature, the proposed development-based model was found to have superior ability to explain certain variables of interest for the study of buyer-seller relationships, such as long-term relationship orientation, information sharing, behavioral loyalty and future intentions.

Although the development-based trust model is less parsimonious than the characteristic-based trust model, it brings more information from the managerial point of view because it makes it possible to identify the type of trust that the client holds. It is also more theoretically sound because it was grounded on a solid theory while the characteristic-based model has been challenged as a true measure of trust (Mayer et al., 1995). 
From a theoretical point of view, the measurement model proposed here satisfies reasonably well the three criteria for evaluation of theories suggested by Sheth, Gardner and Garrett (1988). First, from a syntactic point of view, the sub-constructs of the development-based trust model are properly defined and integrated into a nomological network, satisfying the structure criterion. Further, the hypotheses involving these three sub-constructs and the dependent variables used to test the models are clearly specified and delimited.

From a semantic point of view, we have demonstrated that the model is testable and has received empirical support from data obtained from one sample of clients of an IT wholesaler. However, it must be made clear that this is also one of the main limitations of our study and the model needs to be tested with different samples of respondents in order to increase its empirical support. By analyzing a sample of respondents evaluating their relationships with only one wholesaler of IT products, we were able to increase the internal validity of the model. However, future tests of the model should address this limitation by including respondents evaluating their relationship with different wholesalers so as to increase the model's external validity. Future studies should also analyze other relationship settings such as buyers and sellers transacting services or types of industrial products other than IT products.

Finally, our model also satisfies the pragmatic criteria since it can be applied in practice by both scholars and marketing practitioners. In this respect, a multidimensional trust scale that recognizes that trust can evolve as the relationship matures provides information for marketing managers to identify the nature of trust that their clients grant to their company and act accordingly. For a client whose trust is predominantly calculus-based, suppliers must recognize that trust is frail and the slightest failure may lead to a relationship breakup. At this level of trust, the client preserves the relationship solely because it is worthwhile though he is ready to change to a supplier that offers more advantages and come back as soon as the original supplier beats them.

For those clients who have evolved to knowledge-based trust, the supplier must know that trust is more robust and the relationship more stable. As long as the supplier remains predictable, that is, confirming positive past results and acting consistently (Lewicki \& Bunker, 1995), it is more likely that the clients will be willing to maintain the relationship. Knowledge-based trust is especially important because few of the relationships evolve to the identification-based trust level (Lewicki \& Bunker, 1995) and most of the clients are to be found at this stage.

At the identification-based trust level, clients understand, agree with and approve of the supplier's attitudes. At this level of trust, the relationship is very strong and clients have total trust in their supplier. Furthermore, minor failures are not enough to shatter the relationship. The group that holds an identification-based trust is the most important group for any business because they tend to be less calculative and more oriented towards a long-term relationship.

Despite the significant results presented here, the cross-sectional nature of this study must be taken into account. A more interesting approach would be to analyze how trust develops over time using a longitudinal method. Future studies should concentrate on refining the proposed scales and obtaining data that attempt to capture the evolving nature of trust through longitudinal studies.

\section{REFERENCES}

Anderson, E., \& Weitz, B. A. (1989). Determinants of continuity in conventional industrial channel dyads. Marketing Science, 8(4), 310-323.

Anderson, J. C., \& Gerbing, D. W. (1982). Some methods for re-specifying measurement models to obtain unidimensional construct measurement. Journal of Marketing Research, 19(4), 453-460.

Anderson, J. C., \& Gerbing, D. W. (1998). Structural equation modeling in practice: a review and 
recommended two-step approach. Psychological Bulletin, 103(5), 204-215.

Anderson, J. C., \& Narus, J. A. (1990). A model of distributor firm and manufacturer firm working partnerships. Journal of Marketing, 54(1), 44-53.

Bagozzi, R. P., Yi, Y., \& Philips, L. W. (1991). Assessing construct validity in organizational research. Administrative Science Quarterly, 36(3), 421-458.

Bentler, P. M. (1990). Comparative fit indexes in structural models. Psychological Bulletin, 107(2), 238-246.

Bhattacherjee, A. (2002). Individual trust in online firms: scale development and initial test. Journal of Management Systems, 19(1), 211-241.

Boon, S. D., \& Holmes, J. G. (1991). The dynamics of interpersonal trust: resolving uncertainty in the face of risk. In R. A. Hinde \& J. Groebel (Eds.). Cooperation and prosocial behavior (pp. 190211). Cambridge: Cambridge University Press.

Butler, J. K., Jr. (1991). Toward understanding and measuring conditions of trust: evolution of a conditions of trust inventory. Journal of Management, 17(3), 643-663.

Churchill, G. A., Jr. (1979). A paradigm for developing better measures of marketing constructs. Journal of Marketing Research, 16(1), 64-73.

Coderre, F., Mathieu, A., \& St-Laurent, N. (2004). Comparison of the quality of qualitative data obtained through telephone, postal, and email surveys. International Journal of Market Research, 46(3), 347-357.

Coleman, J. (1990). Foundations of social theory. Massachusetts: Harvard University Press.

Coulter, K. S., \& Coulter, R. A. (2002). Determinants of trust in a service provider: the moderating role of length of relationship. The Journal of Services Marketing, 16(1), 35-50.

Delgado-Ballester, E., Munuera-Alemán, J. L., \& Yagüe-Guillén, M. J. (2003). Development and validation of a brand trust scale. International Journal of Market Research, 45(1), 35-53.

Deutskens, E., Ruyter, K., \& Wetzels, M. (2006). An assessment of equivalence between online and mail surveys in service research. Journal of Service Research, 8(4), 346-355.

Dick, A. S., \& Basu, K. (1994). Customer loyalty: toward an integrated conceptual framework. Journal of the Academy of Marketing Science, 22(2), 99-113.

Dodds, W. B., Monroe, K. B., \& Grewal, D. (1991). Effect of price, brand, and store information on buyers' product evaluations. Journal of Marketing Research, 28, 307-319.

Doney, P. M., \& Cannon, J. P. (1997). An examination of the nature of trust in buyer-seller relationships. Journal of Marketing, 61(2), 35-51.

Doyle, S. X., \& Roth, G. T. (1992). Selling and sales management in action: the use of insight coaching to improve relationship selling. Journal of Personal Selling and Sales Management, 12(1), 59-64.

Dwyer, F. R., Schurr, P. H., \& Oh, S. (1987). Developing buyer-seller relationships. Journal of Marketing, 51, 11-27.

Evans, J. R., \& Mathur, A. (2005). The value of online surveys. Internet Research, 15(2), 195-219.

Farrelly, F., \& Quester, P. (2003). The effects of market orientation on trust and commitment. European Journal of Marketing, 37(3/4), 530-553. 
Fornell, C., \& Larcker, D.F. (1981). Evaluating structural equations with unobservable variables and measurement error. Journal of Marketing Research, 18(2), 39-50.

Gabarro, J. J. (1978). The development of trust influence and expectations. In A. G. Athos \& J. J. Gabarro (Eds.). Interpersonal behavior: communication and understanding in relationship (pp. 290-303s). Upper Saddle River, NJ: Prentice Hall.

Gambetta, D. (1988). Can we trust?. In D. Gambetta (Ed.). Trust: making and breaking cooperative relations (pp. 95-107). New York: Basil, Blackwell.

Ganesan, S. (1994). Determinants of long-term orientation in buyer-seller relationships, Journal of Marketing, 58(4), 1-19.

Geyskens, I., J., Steenkamp, E. M., \& Kumar, N. (1998). Generalizations about trust in marketing channel relationships using meta-analysis. International Journal of Research in Marketing, 15(3), 223-248.

Granovetter, M. S. (1985). Economic action and social structure: the problem of embeddedness. American Journal of Sociology, 91(3), 481-510.

Grönroos, C. (1994). From marketing mix to relationship marketing: toward a paradigm shift in marketing. Management Decision, 32(2), 4-20.

Groves, R. M. (2006). Nonresponse rates and nonresponse bias in household surveys. Public Opinion Quarterly, 70(5), 646-675.

Hair, J. F., Jr., Anderson, R. E., Tatham, R. L., \& Black, W. C. (1998). Multivariate data analysis (5th ed.). Upper Saddle River, NJ: Prentice Hall.

Hosmer, L. T. (1995). Trust: the connecting link between organizational theory and philosophical ethics. Academy of Management Review, 20(2), 379-403.

Hu, L. T., \& Bentler, P. M. (1995). Evaluating model fit. In R. H. Hoyle (Ed.). Structural equation modeling: concepts, issues, and applications (pp. 76-99). Thousand Oaks, CA: Sage.

Jarvis, C. B., Mackenzie, S. B., \& Podsakoff, P. M. (2003). A critical review of construct indicators and measurement model misspecification in marketing and consumer research. Journal of Consumer Research, 30(2), 199-218.

Johnson-George, C., \& Swap, W. C. (1982). Measurement of specific interpersonal trust: construction and validation of a scale to assess trust in a specific other. Journal of Personality and Social Psychology, 43(6), 1306-1317.

Jones, G. R., \& George, J. M. (1998). The experience and evolution of trust: Implications for cooperation and teamwork. Academy of Management Review, 23(3), 531-546.

Jöreskog, K. G., \& Sörbom, D. (1996). LISREL 8: user's reference guide. Chicago: Scientific Software International.

Kee, H. W., \& Know, R. E. (1970). Conceptual and methodological considerations in the study of trust and suspicion. Journal of Conflict Resolution, 14(3), 357-366.

Kingshott, R. P. J. (2006). The impact of psychological contracts upon trust and commitment within supplier-buyer relationships: a social exchange view. Industrial Marketing Management, 35(2), 724-742.

Kotler, P. (1991). Philip Kotler explores the new marketing paradigm. Marketing Science Institute Review, 1, 4-5. 
Kramer, R. M. (1994). The sinister attribution error: paranoid cognition and collective distrust in organizations. Motivation and Emotion, 18(2), 199-230.

Lages, C., Lages, C. R., \& Lages, L. F. (2005). The RELQUAL scale: a measure of relationship quality in export market ventures. Journal of Business Research, 58(8), 1040-1048.

Larzelre, R. E., \& Huston, T. L. (1980). The dyadic trust scale: toward understading interpersonal trust in close relationships, Journal of Marriage and the Family, 42(8), 595-604.

Lewicki, R. J., \& Bunker, B. B. (1995). Trust in relationships: a model of development and decline. In B. B. Bunker \& J. Z. Zubin (Eds.). Conflict, cooperation, and justice (pp. 133-173). San Francisco, CA: Jossey-Bass Publishers.

Lewicki, R. J., McAllister, D. J., \& Bies, R. J. (1998). Trust and distrust: New relationships and realities, Academy of Management Review, 23(3), 438-458.

Lewis, J. D., \& Weigert, A. (1985). Trust as a social reliability. Social Force, 63(4), 967-985.

MacCallum, R. C., Browne, M. W., \& Sugawara, H. M. (1996). Power analysis and determination of sample size for covariance structure modeling. Psychological Methods, 1(2), 130-149.

MacMillan, K., K., Money, A., \& Downing, S. (2005). Relationship marketing in the not-for-profit sector: an extension and application of the commitment-trust theory. Journal of Business Research, 58(6), 806-28.

Mayer, R. C., Davis, J. H., \& Schoorman, F. D. (1995). An integrative model of organizational trust. The Academy of Management Review. 20(3), 709-734.

McDonald, H., \& Adam, S. (2003). A comparison of online and postal data collection methods in marketing research. Marketing Intelligence and Planning, 21(2), 85-95.

McKnight, D. H., \& Chervany, N. L. (2002). What trust means in e-commerce customer relationship: an interdisciplinary conceptual typology. International Journal of Electronic Commerce, 6(2), 35-59.

McKnight, D. H., Choudhury, V., \& Kacmar, C. (2002). Developing and validating trust measures for e-commerce: an integrative typology. Information Systems Research, 13(3), 334-359.

Morgan, R. M., \& Hunt, S. D. (1994). The commitment-trust theory of relationship marketing. Journal of Marketing, 58(3), 20-38.

North, D. C. (1990). Institutions, institutional change, and economic performance. New York: Cambridge University Press.

Nunnally, J.C. (1978). Psychometric theory (2nd ed.). New York: McGraw-Hill.

Pavlou, P. A. (2002). Institutional trust in interorganizational exchange relationships: The role of electronic B2B marketplaces. Journal of Strategic Information Systems, 11(3/4), 215-243.

Rempel, J. K., Holmes, J. G., \& Zanna, M. P. (1985). Trust in close relationships. Journal of Personality and Social Psychology, 49(1), 95-112.

Roster, C. A., Rogers, R. D., Albau, G., \& Klein, D. (2004). A comparison of response characteristics from web and telephone surveys. International Journal of Market Research, 46(3), 359- 373.

Rotter, J. B. (1967). A new scale for the measurement of interpersonal trust. Journal of Personality, 35(4), 651-665.

Rotter, J. B. (1971). Generalized expectancies for interpersonal trust. American Psychologist, 26(5), 443-452. 
Rousseau, D. M., Sitkin, S. B., Burt, R. S., \& Camerer, C. (1998). Not so different after all: a crossdiscipline view of trust. Academy of Management Review, 23(3), 393-404.

Schwab, D. P. (1980). Construct validity in organization behavior. In B. M. Staw \& L. L. Cummings (Eds.). Research in organizational behavior (Vol. 2, pp. 3-44). Greenwich, CT: JAI Pres.

Selnes, F. (1998). Antecedents and consequences of trust and satisfaction in buyer-seller relationships. European Journal of Marketing, 32(3), 305-322.

Shapiro, D. B. Sheppard, H., \& Cheraskin, L. (1992). Business on a handshake. Negotiation Journal, 8(4), 365-377.

Shapiro, S. P. (1987). The social control of impersonal trust. American Journal of Sociology, 93(3), 623-658.

Sheth, J. N., Gardner, D. M., \& Garrett, D. E. (1988). Marketing theory. Evolution and evaluation. New York: John Wiley.

Shih, T., Fan, X. (2008). Comparing response rates from Web and mail-surveys: a meta-analysis, Field Methods, 20(3), 249-271.

Singer, E. (2006). Introduction: nonresponse bias in household surveys. Public Opinion Quarterly, 70(5), 637-645.

Sirdeshmukh, D., Singh, J., \& Sabol, B. (2002). Consumer trust, value, and loyalty in relational exchange. Journal of Marketing, 66(1), 15-37.

Webster, F. E. (1992). The changing role of marketing in the corporation. Journal of Marketing, 56(4), 1-18.

Williamson, O. E. (1993). Calculativeness, trust, and economic organization. Journal of Law \& Economics, 36(1), 453-486.

Wong, A., \& Sohal, A. (2002). An examination of the relationship between trust, commitment, and relationship quality. International Journal of Retail \& Distribution Management, 30(1), 34-50.

Worchel, P. (1979). Trust and distrust. In W. G. Austin \& S. Worchel (Eds.). The social psychology of intergroup relations (pp. 157-187). Monterey, CA: Brooks/Cole.

Wrightsman, L. S. (1991). Interpersonal trust and attitudes toward human nature. In J. P. Robinson, P. R. Shaver, \& L. S. Wrightsman (Eds.). Measures of personality and social psychological attitudes (Vol. 1, pp. 373-412). San Diego: Academic Press.

Zeithaml V. A. (1988). Consumer perceptions of price, quality, and value: a means-end model and synthesis of evidence. Journal of Marketing, 52(3), 2-22.

Zhao, Y., \& Cavusgil, S. T. (2006). The effect of supplier's market orientation on manufacturers' trust. Industrial Marketing Management, 35(4), 405-414.

Zucker, L. G. (1986). Production of trust: institutional sources of economic structure, 1840-1920. In B. M. Staw \& L. L. Cummings (Eds.). Research in organization behavior (Vol. 8, pp. 53-111). Greenwich, CN: JAI Press. 


\section{APPENDIX 1}

\section{Construct Items, Means and Standard Deviations}

\section{Calculus-based Trust}

\section{Construct Items}

Mean

3.1 other distributors

CAL2 I always expect that buying from this wholesaler will be more convenient than buying from most other distributors

CAL3 I always expect the commercial terms of the wholesaler to be more favorable than those offered by most other distributors

CAL4* I always expect the wholesaler to be able to offer products and brands that other distributors do not offer*

\section{Knowledge-based Trust}

KN1 Most of my previous experiences with the wholesaler were positive

KN2

KN3

KN4* Most of the times I purchased from the wholesaler I had no problems Most of the times I purchased from the wholesaler I was satisfied Based on my previous experience with the wholesaler I feel I am buying at the right place*

\section{Identification-based Trust}

ID1 I have great respect for the wholesaler

ID2

ID3

ID4*

I feel happy about buying from the wholesaler

I feel good about buying from the wholesaler

I have strong emotional ties with the wholesaler*

\section{Characteristic-based Trust}

CAR1 The wholesaler is concerned about the well-being of his clients

CAR2 The wholesaler tries to help his clients rather than just look out for himself

CAR3 The wholesaler keeps his promises

CAR4

CAR5

CAR6

The wholesaler backs up his words with actions

The wholesaler is competent at what he does

The wholesaler has a lot of experience in the business

\section{Relationship Quality - Information Sharing}

IS1 I discuss strategic issues of my business with the wholesaler 3.0

IS2 I share confidential information with the wholesaler

IS3 I talk to the wholesaler about our business strategies

\section{Relationship Quality - Long-term Relationship Orientation}

LT1 It is important for me to keep a long-term relationship with the wholesaler

LT2 My relationship with the wholesaler is based on long-term objectives

\section{Future Intentions}

FI1 Do you intend to continue buying from the wholesaler in the future?

FI2

FI3

FI4 Will the wholesaler feature among your key suppliers in the future?

Do you intend to recommend the wholesaler to your friends in the future?

Do you intend to recommend the wholesaler to IT product manufacturers in the future?

\section{Behavioral Loyalty}

BI1 From how many different distributors did you buy last year?

*Items dropped from the final scale. 


\section{APPENDIX 2}

\section{Correlation Matrix}

\begin{tabular}{|c|c|c|c|c|c|c|c|c|c|c|c|c|c|c|c|c|c|c|c|c|c|c|c|c|c|c|c|c|}
\hline & CAL1 & CAL2 & CAL3 & KN1 & KN2 & KN3 & ID1 & ID2 & ID3 & CAR1 & CAR2 & CAR3 & CAR4 & CAR5 & CAR6 & IS1 & IS2 & IS3 & LT1 & LT2 & BL1 & BL2 & BL3 & FI1 & FI2 & FI3 & FI4 & MONT \\
\hline CAL2 & 0.45 & & & & & & & & & & & & & & & & & & & & & & & & & & & \\
\hline CAL3 & 0.58 & 0.51 & & & & & & & & & & & & & & & & & & & & & & & & & & \\
\hline KN1 & 0.28 & 0.36 & 0.34 & & & & & & & & & & & & & & & & & & & & & & & & & \\
\hline KN2 & 0.21 & 0.31 & 0.23 & 0.65 & & & & & & & & & & & & & & & & & & & & & & & & \\
\hline KN3 & 0.29 & 0.40 & 0.30 & 0.74 & 0.62 & & & & & & & & & & & & & & & & & & & & & & & \\
\hline ID1 & 0.20 & 0.45 & 0.28 & 0.39 & 0.31 & 0.38 & & & & & & & & & & & & & & & & & & & & & & \\
\hline ID3 & 0.34 & 0.48 & 0.37 & 0.56 & 0.40 & 0.58 & 0.56 & 0.72 & & & & & & & & & & & & & & & & & & & & \\
\hline CAR1 & 0.30 & 0.35 & 0.32 & 0.43 & 0.34 & 0.39 & 0.51 & 0.52 & 0.58 & & & & & & & & & & & & & & & & & & & \\
\hline CAR2 & 0.34 & 0.40 & 0.42 & 0.50 & 0.38 & 0.45 & 0.39 & 0.36 & 0.49 & 0.57 & & & & & & & & & & & & & & & & & & \\
\hline CAR3 & 0.27 & 0.37 & 0.31 & 0.68 & 0.57 & 0.65 & 0.38 & 0.44 & 0.54 & 0.40 & 0.49 & & & & & & & & & & & & & & & & & \\
\hline CAR4 & 0.24 & 0.42 & 0.33 & 0.57 & 0.46 & 0.56 & 0.48 & 0.49 & 0.53 & 0.47 & 0.52 & 0.62 & & & & & & & & & & & & & & & & \\
\hline CAR5 & 0.41 & 0.41 & 0.39 & 0.69 & 0.59 & 0.62 & 0.39 & 0.48 & 0.57 & 0.46 & 0.48 & 0.66 & 0.59 & & & & & & & & & & & & & & & \\
\hline IS1 & 0.33 & 0.41 & 0.36 & 0.24 & 0.09 & 0.22 & 0.38 & 0.32 & 0.34 & 0.35 & 0.37 & 0.17 & 0.24 & 0.19 & 0.28 & & & & & & & & & & & & & \\
\hline IS2 & 0.28 & 0.36 & 0.25 & 0.27 & 0.12 & 0.25 & 0.40 & 0.34 & 0.37 & 0.36 & 0.34 & 0.28 & 0.32 & 0.27 & 0.31 & 0.53 & & & & & & & & & & & & \\
\hline IS3 & 0.32 & 0.43 & 0.31 & 0.27 & 0.15 & 0.28 & 0.37 & 0.33 & 0.41 & 0.36 & 0.36 & 0.17 & 0.28 & 0.25 & 0.29 & 0.77 & 0.52 & & & & & & & & & & & \\
\hline LT1 & 0.19 & 0.34 & 0.20 & 0.46 & 0.35 & 0.44 & 0.41 & 0.47 & 0.45 & 0.35 & 0.36 & 0.46 & 0.43 & 0.46 & 0.38 & 0.29 & 0.25 & 0.23 & & & & & & & & & & \\
\hline LT2 & 0.17 & 0.31 & 0.27 & 0.29 & 0.13 & 0.24 & 0.31 & 0.33 & 0.33 & 0.29 & 0.33 & 0.31 & 0.38 & 0.27 & 0.29 & 0.37 & 0.33 & 0.33 & 0.49 & & & & & & & & & \\
\hline BL1 & 0.09 & 0.14 & 0.13 & 0.09 & 0.04 & 0.05 & 0.13 & 0.12 & 0.14 & 0.12 & 0.12 & 0.09 & 0.09 & 0.08 & -0.02 & 0.14 & 0.13 & 0.11 & 0.05 & 0.12 & & & & & & & & \\
\hline BL2 & 0.26 & 0.45 & 0.30 & 0.22 & 0.19 & 0.27 & 0.39 & 0.34 & 0.33 & 0.34 & 0.33 & 0.24 & 0.27 & 0.28 & 0.22 & 0.36 & 0.29 & 0.37 & 0.29 & 0.25 & 0.51 & & & & & & & \\
\hline BL3 & 0.32 & 0.49 & 0.34 & 0.26 & 0.18 & 0.27 & 0.37 & 0.36 & 0.32 & 0.35 & 0.37 & 0.29 & 0.29 & 0.30 & 0.25 & 0.38 & 0.35 & 0.34 & 0.33 & 0.26 & 0.42 & 0.75 & & & & & & \\
\hline
\end{tabular}

Continues 


\section{Correlation Matrix (continued)}

\begin{tabular}{|c|c|c|c|c|c|c|c|c|c|c|c|c|c|c|c|c|c|c|c|c|c|c|c|c|c|c|c|c|}
\hline & CAL1 & CAL2 & AL3 & KN1 & KN2 & KN3 & ID1 & ID2 & ID3 & CAR1 & CAR2 & CAR3 & CAR4 & CAR5 & CAR6 & IS1 & IS2 & IS3 & LT1 & LT2 & BL1 & BL2 & BL3 & FI1 & FI2 & FI3 & FI4 & MONT \\
\hline FI1 & 0.22 & 0.26 & 0.17 & 0.45 & 0.34 & 0.47 & 0.32 & 0.40 & & 0.32 & 0.37 & 0.46 & & & 0.40 & 0.24 & 0.21 & 0.24 & & 0.24 & -0.02 & 0.26 & 0.36 & & & & & \\
\hline FI2 & 0.31 & 0.40 & 0.26 & 0.52 & 0.45 & 0.51 & 0.45 & 0.46 & & & ילם. & 0.45 & & & 0.45 & & 31 & 0.36 & & 0.31 & & & 0.43 & & & & & \\
\hline FI3 & & 0.33 & & & & & & & & 0.41 & 0.43 & 0.38 & 0.39 & 0.49 & 0.48 & & 0.35 & 0.33 & 0.30 & 0.22 & 0.02 & 0.30 & 0.27 & 0.55 & 0.65 & & & \\
\hline FI4 & 0.28 & 0.38 & 0.28 & 0.36 & 0.34 & 0.39 & 0.45 & 0.43 & 0.45 & 0.40 & 0.35 & 0.33 & 0.34 & 0.44 & 0.36 & 0.24 & 0.31 & 0.28 & 0.32 & 0.27 & 0.04 & 0.34 & 0.29 & 0.52 & 0.67 & & & \\
\hline MONT & 0.08 & 0.06 & 0.05 & 0.01 & 0.07 & 0.02 & 0.16 & 0.13 & 0.12 & 0.08 & 0.18 & 0.10 & 0.14 & 0.11 & 0.09 & 0.09 & & 0.11 & 0.12 & 0.00 & 0.09 & 0.12 & 0.13 & 0.11 & 0.11 & 0.07 & 0.10 & \\
\hline AVGVAL & 0.21 & 0.26 & 0.17 & 0.01 & 0.09 & 0.08 & 0.20 & 0.12 & 0.14 & 0.18 & 0.20 & 0.11 & 0.18 & 0.10 & 0.09 & 0.28 & 0.26 & 0.25 & 0.12 & 0.16 & 0.21 & 0.31 & 0.38 & 0.09 & 0.14 & 0.13 & 0.15 & 0.23 \\
\hline
\end{tabular}

